
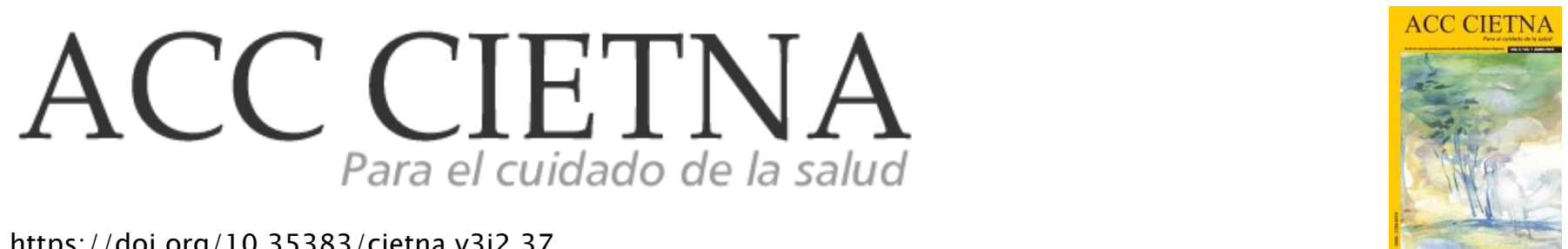

https://doi.org/10.35383/cietna.v3i2.37

EDITORIAL

\title{
ENFERMERÍA PROFESIÓN DE NIVEL, COMPROMETIDA Y PODEROSA
}

\section{Cervera Vallejos, Mirtha Flor ${ }^{1}$}

\section{INFORMACIÓN DEL ARTÍCULO \\ Historia del artículo:}

Recibido el 23 de octubre de 2016

Aceptado el 15 de noviembre de 2016

\section{Palabras claves:}

Enfermería

Cuidado humano

Persona

\section{RESUMEN}

El campo de la salud es el lugar donde se producen los hechos decisivos para la vida del hombre, donde nace, vive experiencias que sellan con fuerza el cuerpo y el espíritu, y muere...determinando cambios profundos en el estilo de vida dentro de la sociedad, la familia y a menudo en las actitudes psíquicas y espirituales de cada persona.

Forman parte de estos cambios los enfermeros lambayecanos, cuyo número asciende a más de tres mil, quienes conjugan en forma eficiente sus competencias en el saber conocer, saber hacer y sobre todo saber ser, para el pronto restablecimiento de la salud de quienes cuidan en los diferentes niveles de atención, salud resquebrajada por la variedad de patologías conocidas y desconocidas.

Desde una perspectiva de sistemas tanto en los enfermeros que cuidan como en las personas que son cuidadas, están los cambios demográficos, generados tanto por la disminución de la mortalidad como de la natalidad, y por el incremento en la esperanza de vida con el respectivo envejecimiento de la población, donde la ayuda familiar es indispensable.

En todos estos avatares, la historia de la enfermería nos devela cómo la acción de cuidar estuvo presente desde los orígenes del ser humano, mucho antes que su teorización y conceptualización, por tanto el cuidado es inherente a la vida, revela su íntima constitución; sin el cuidado no hubiera sido posible la existencia humana, menos aún la familia y las comunidades que conforman las diferentes poblaciones del planeta.

Entonces es claro que el objetivo del cuidado radica en ayudar a las personas mediante un proceso de transacciones humanas a encontrar un significado a la experiencia de enfermar, adquirir auto conocimiento,

\footnotetext{
${ }^{1}$ Doctora en Enfermería. Docente en la Escuela de Enfermería de la Universidad Católica Santo Toribio de Mogrovejo, Chiclayo, Perú.
} 
autocontrol y auto curación, para restablecer su armonía, independientemente de las circunstancias externas, aspectos que a diario realizan los enfermeros logrados entre la lucha profesional para ser mejores y el contacto con el sufrimiento de quienes cuidan.

Sin embargo, hay que recordar el cuidado humanizado con la finalidad de no olvidarlo, pues a veces no somos oportunos en ello porque el avance de la ciencia y la tecnología nos abruma y la persona humana no puede quedar al vaivén de esta para vivir o morir, para prolongar una vida con obstinación terapéutica, o protegiéndola hasta el final de forma natural. Como expresaban algunas enfermeras "... Si bien es cierto ellos ya no sienten, no ven, pero están vivos y se les tiene que cuidar. Las situaciones son diferentes y cada uno de los pacientes que atendemos merecen un respeto y un cuidado..." Los enfermeros son conscientes al darse cuenta que la persona que cuida tienen un valor en sí mismo, y no por ciertos efectos que de él resultan o como simples medios. Lo que tenemos que hacer es siempre procurar cuidar hasta el final reconociendo en todo momento la dignidad de la persona, porque enfermería es una profesión comprometida y generosa.

Recuerdo lo que expresaba una colega enfermera al acoger a un micro prematuro: "...se le hizo todo, empezando por el bautismo porque respiraba... no duró mucho por su inmadurez". Las enfermeras reconocen el valor intrínseco de la persona, su dignidad ontológica, encontrada en su propio ser, incluso haciéndola capaz de hacer frente a tareas morales, preocupándose no solo de su vida biológica sino también espiritual. Bautizar a un micro prematuro es hacerlo hijo de Dios, permitiéndole contemplar a Quien le dio la vida y ahora para siempre... por eso afirmo que la labor de enfermería, muchas veces ejercida silenciosamente, tiene un gran nivel y cuyo potencial desde el cuidado es increíble.

Es imprescindible entender como profesional enfermero que soy yo persona que cuida a otra persona, tenemos por centro de atención y cuidado a la persona enferma, considerada en su unitotalidad y por eso sagrada, merecedora de todo respeto. $Y$ esta sacralidad exige ser reconocida y profesada en toda circunstancia por ser inviolable e irrenunciable. La sacralidad es la raíz de donde nacen todas las prerrogativas humanas: Las que constituyen el misterio de la personalidad individual y las que hacen de la persona un miembro constitutivo de la sociedad.

Una acción profesional que no tome en cuenta a la persona se transforma en irresponsable. Por el contrario un obrar responsable es aquel que no se desentiende de los resultados pertinentes o que puedan afectarla como por ejemplo un cuidado deshumanizado que hace que el enfermo permanezca en el hospital más de lo debido o traiga consigo alguna secuela que le disminuye vitalidad... por eso Watson llega afirmar que la ocasión para el cuidado humano es creada. Ambas personas, enfermera y ser cuidado tienen la posibilidad de vivir juntos 
una transacción humana, que exige un profundo compromiso. Esta forma de cuidar se practica usando las relaciones interpersonales ya que los procesos humanos intersubjetivos mantienen vivo un sentir común de humanidad, la identificación de sí mismo con los otros, para saber que necesitan de mí.

Consecuentemente Watson increpa a la enfermera a sostener y fomentar la fe y la esperanza, porque el cuidado humano incorpora valores profundamente humanos, altruistas que facilitan la promoción de una asistencia de enfermería holística, y potencia la salud de los pacientes, permitiéndoles que cultiven su sistema de creencias $y$ ejecuten sus rituales de manera que se les ayude a mantener la fe en ellos mismos y en Dios. Así lo expresaba un familiar acompañante de una persona con cáncer "...le hacen orar, una enfermera una vez nos dijo que cuando ya no tengamos fuerzas que oremos y que en esa oración encontraremos la fuerza que necesitamos"...

La enfermera debe capacitarse continuamente, pero también preocuparse en reforzar su fe y esperanza en sí misma, en la energía que emana su espíritu, quizá no tomada en cuenta por el activismo profesional que muchas veces realiza para procurar el bienestar del que sufre, aun así con su propio potencial y en el de la persona que cuida... con ello se dará cuenta que, incluso cuando médicamente no queda nada más que hacer, puede potenciar la fe y la esperanza en Alguien más allá de sí mismo.

Por ello, concluyo, el acceso al cuerpo, a la mente y al corazón de una persona es posible siempre que la enfermera la perciba como una totalidad y se trace como meta crecer en una de sus competencias más olvidadas "saber ser". 
NURSING PROFESSION LEVEL, COMMITTED AND POWERFUL

\section{ABSTRACT}

Keywords:

Nurse

Human care

Person
The field of health is the place where the decisive events occur for the life of man, where he is born, experiences experiences that seals with force the body and the spirit, and dies ... determining profound changes in the life style within the society, The family and often in the psychic and spiritual attitudes of each person.

These changes include the Lambayeque nurses, whose number amounts to more than three thousand, who efficiently combine their competences in knowing, knowing how to do and especially knowing how to be, for the early restoration of the health of those who care in the Different levels of care, health cracked by the variety of known and unknown pathologies.

From a systems perspective in both nurses who care for and care for people, there are the demographic changes, generated both by the decrease in mortality and the birth rate, and by the increase in the life expectancy with the respective aging Of the population, where family support is indispensable.

In all these avatars, the history of nursing reveals how the action of caring was present from the origins of the human being, long before its theorization and conceptualization, therefore care is inherent in life, reveals its intimate constitution; Without care human existence would not have been possible, let alone the family and communities that make up the different populations of the planet.

So it is clear that the goal of care is to help people through a process of human transactions to find meaning in the experience of getting sick, gaining self-knowledge, self-control and self-healing, to restore their harmony regardless of external circumstances, Aspects that nurses achieve daily between the professional struggle to be better and the contact with the suffering of those who care.

However, we must remember the humanized care with the purpose of not forgetting, because sometimes we are not timely in this because the advance of science and technology overwhelms us and the human person can not stay to the swing of this to live or die, To prolong a life with therapeutic obstinacy, or protecting it to the end naturally. As some nurses expressed "... While it is true they no longer feel, they do not see, but they are alive and they have to take care of them. The situations are different and each of the patients we attend deserve respect and care ... "Nurses are aware when they realize that the caregiver has a value in itself, not because of certain effects that result from it or as Simple means. What we have to do is always seek to care until the end recognizing at all times the dignity of the person, because nursing is a profession committed and generous.

I remember what a nurse colleague expressed when she welcomed a premature baby: "... everything was done, starting with baptism because 
it breathed ... it did not last long because of its immaturity". Nurses recognize the intrinsic worth of the person, their ontological dignity, found in their own being, even making them capable of facing moral tasks, worrying not only about their biological life but also about their spiritual life. To baptize a premature baby is to make him son of God, allowing him to contemplate who gave him life and now forever ...that is why I affirm that nursing work, often exercised silently, has a great level and whose potential from the care is incredible.

It is imperative to understand as a professional nurse that I am a person who cares for another person, we have as a center of attention and care the sick person, considered in his unitotality and therefore sacred, deserving of all respect. And this sacredness demands to be recognized and professed in every circumstance for being inviolable and inalienable. Sacrality is the root from which all human prerogatives are born: Those that constitute the mystery of the individual personality and those that make the person a constituent member of society.

A professional action that does not take into account the person becomes irresponsible. On the contrary, a responsible action is one that does not ignore the pertinent results or that may affect it, such as a dehumanized care that causes the patient to stay in the hospital more than he should or bring with him a sequel that decreases

vitality ... That Watson comes to affirm that the occasion for human care is created. Both people, nurse and care have the possibility of living together a human transaction, which requires a deep commitment. This way of caring is practiced using interpersonal relationships because intersubjective human processes keep alive a common sense of humanity, identifying oneself with others, to know that they need me. Consequently, Watson urges the nurse to uphold and foster faith and hope, because human care incorporates deeply human, altruistic values that facilitate the promotion of holistic nursing care, and enhances the health of patients by allowing them to cultivate their system Of beliefs and perform their rituals in a way that helps them to maintain faith in themselves and in God. This is what an accompanying family member of a person with cáncer said "... they make you pray, a nurse once told us that when we no longer have the strength to pray and in that sentence we will find the strength we need" ...The nurse must continually train herself, but also be concerned with reinforcing her faith and hope in herself, in the energy that emanates her spirit, perhaps not taken into account by the professional activism she often performs to procure the well-being of the suffering, With your own potential and that of the person you care for ... you will realize that even when there is nothing left to do, you can strengthen faith and hope in someone beyond yourself. 